\title{
Türkiye Ekonomisinde Sektörel Enerji Tüketiminin Ayrıştırma Yöntemiyle Analizi
}

\begin{abstract}
Alper YILMAZ ${ }^{1}$
Serap ÜRÜT KELLECI ${ }^{2} \quad$ Aziz BOSTAN ${ }^{3}$

$\ddot{O}_{z}$

Çalışmada, 1970-2013 dönemi için Türkiye ekonomisinde sektörel enerji tüketimi toplamsal tipte ayrıştırma analizi yöntemiyle analiz edilmiştir. Analiz sonuçlarl, sektörel enerji tüketiminin çıktı ve yapısal etki nedeniyle arttı̆̆nı, yoğunluk etkisi nedeniyle ise düştügünü göstermektedir. Çıktı etkisinin sektörel enerji tüketimi üzerinde daha fazla etkili olduğu ve sektörel enerji tüketiminin üretim artışı ile oldukça yakın ilişkili olduğu sonucuna ulaşılmıştır. Benzer şekilde yapısal etkinin, Türkiye ekonomisindeki enerji yoğun sektörlerinin ă̆ırlığının artmasına bağlı olarak sektörel enerji tüketimini arttırıc yönde etki yaptığl görülmüştür. Ancak yoğunluk etkisine bakıldı̆̆ında, 1980 sonrasında Türkiye ekonomisinde enerji yoğunluğunun yavaş bir düşme eğilimi içinde olduğu ve enerji tüketimini düşürücü etki yaptığı söylenebilir.

Anahtar Kelimeler: Sektörel enerji tüketimi, Ayrıştırma Analizi, Türkiye Ekonomisi

JEL Sinıflandırma Kodlart: C25, Q20, L60

\section{The Decomposition Method of Energy Sector Analysis in the Turkish Economy}

\section{Abstract}

This paper aims to investigate the sectoral energy use in Turkish economy for the 1970 to 2013 periods. For this purpose we employ Logarithmic Mean Divisia Index method. The results indicate that, the primary energy consumption has been increased as a result of production and structural effect but decreased as for intensity effect. Also production effect has the strongest influence on primary energy consumption in accordance with other two effects. Structure effect has been come to conclusion as positive correlation with energy consumption because of increase in relative share of energy intensive sectors in GDP. However results for intensity effect shows that after 1980 period, there has been moderate decrease in energy intensity in Turkish economy and so have negative effect on sektorial energy consumption.
\end{abstract}

Keywords: Sectoral Energy Consumption, Decomposition Method, Turkish Economy

JEL Classification Codes: C25, Q20, L60

${ }^{1}$ Yrd. Doç. Dr., Adnan Menderes Üniversitesi, Söke İşletme Fakültesi, Uluslararası Ticaret ve İşletmecilik Bölümü, alper.yilmaz@adu.edu.tr

${ }^{2}$ Yrd. Doç. Dr., Aksaray Üniversitesi, İktisadi ve İdari Bilimler Fakültesi, Maliye Bölümü, serapkelleci@aksaray.edu.tr

${ }^{3}$ Yrd. Doç. Dr., Adnan Menderes Üniversitesi, Söke İşletme Fakültesi, İktisat Bölümü, azbostan@hotmail.com 


\section{A.YILMAZ - S. Ü. KELLECİ - A. BOSTAN}

\section{GİRIŞ}

Türkiye ekonomisi, 76 milyonluk genç ve büyüyen nüfusuyla yeni endüstrileşmiş yükselen piyasa ekonomileri içinde yer almaktadır. 2014 yıl sonu itibariyle milli geliri 832 milyar \$’a kişi başı geliri 10.079 \$'a çıkmıştır. Ancak 2009 yılında yaşanan küresel finansal kriz Türkiye ekonomisini de olumsuz etkilemiş ve ekonomi \%4,7 küçülmüştür. IMF'nin Dünya Ekonomik Görünüm (WEO) 2010 raporuna göre, krizin ilk şok dalgasının atlatılmasıyla Türkiye ekonomisi kademeli olarak iyileşmeye başlamış ve 2011 itibariyle ekonomik büyüme \%8,9 olarak gerçekleşmiştir. Şu anda AB'ye göre Türkiye, önümüzdeki yıllarda iyi bir büyüme trendi yakalayacak ülkeler arasında sayılmaktadır. Yine OECD’ye göre 2011-2017 yılları arasında yıllık ortalama \%6,8 büyüme oranıyla OECD ülkeleri içindeTürkiye'ninen hılı büyüyen ülkelerden biri olması beklenmektedir (RME-Turkey Economic Outlook, 26-27). Bu bağlamda dinamik ekonomisiyle Türkiye,dünyada enerji tüketimi en hızlı artan ülkelerden biridir ve enerji sektörü önemli bir gelişme potansiyeli barındırmaktadır.

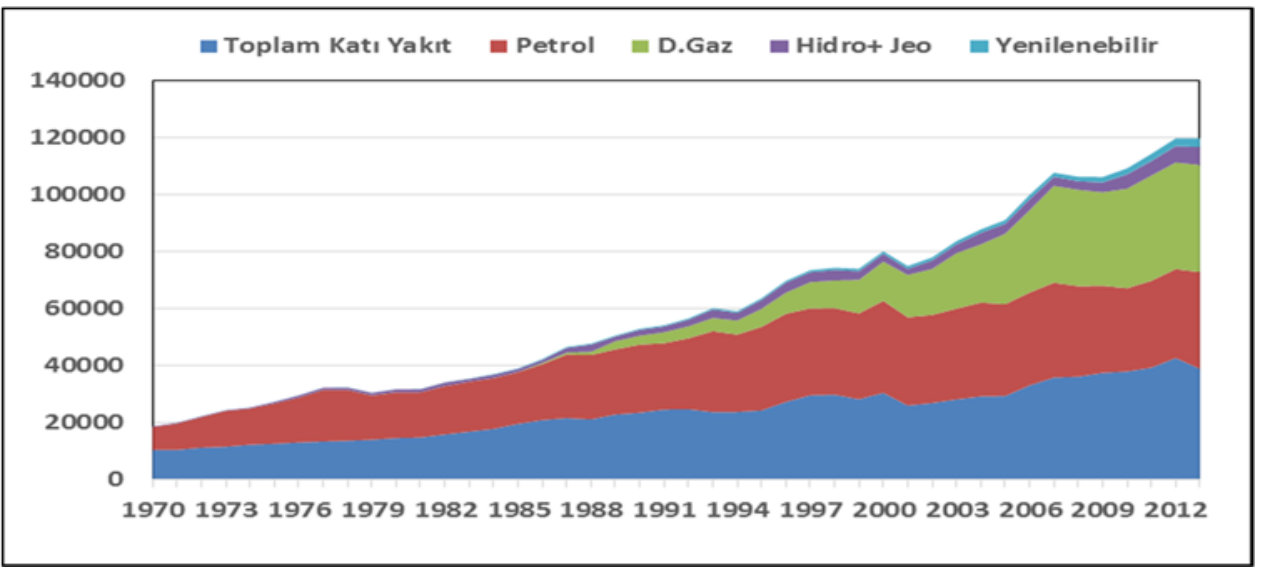

Şekil 1. TürkiyeEkonomisinde Kaynaklara Göre Enerji Tüketimi (Mtep) (ETKB, Enerji Dengesi Tabloları, 1970-2013)

Şekil 1'de Türkiye'nin birincil enerji tüketimi gösterilmiştir. Enerji ve Tabii Kaynaklar Bakanlığı'nın verilerine göre, 1970 yılında 18.872 Btep olan tüketim 2013 y1lında 120.291 Btep'ye, kişi başı tüketim ise 534 kep'den 1.603 kep'ye 
çıkmıştır. Fakat bu seviye hala gelişmiş ülkelerin gerisindedir. Kriz yılları hariç (1994, 2001 ve 2008) tüketim seviyesi sürekli yükselmiş ve dönem başından günümüze ortalama \%4,6 oranında artmıştır. Özellikle son dönemlerde Türkiye ekonomisinde meydana gelen olumlu gelişmelerle, 2002-2007 arasında enerji tüketimartışı ortalama \%6,13 olarak gerçekleşmiştir.

Tüketim demetine bakıldı̆̆ında 1970 yılında katı yakıtlar (taş kömürü, linyit, asfaltit, petrol koku, odun, hayvan ve bitki artıkları) \%56,3 ile ilk sıradadır. Onu $\% 42,2$ ile petrol ve \%1,5 ile hidro ve yenilenebilir enerji kaynakları takip etmektedir. Ancak bu yapı yıllar itibariyle önemli değişikliklere uğramıştır. 2013 yılına gelindiğinde son üç dönem boyunca katı yakıtların ve petrolün payı azalarak sırasıyla \%32,4 ve \%28,2'ye gerilediği gözlenmiştir. Diğer yandan doğal gazın pay1 1986 yılında \%1'iken 2013 yılında \%31,3 olduğu tespit edilmiştir. Ayrıca hidrolik enerji ve yenilenebilir enerjinin payı da 7 puan artarak \%8,1'e çıkmıştır. Kısacası, katı yakıtlar ve petrolün tüketim içindeki payı giderek azalmaktadır. Buna karşılık henüz yeni olmasına rağmen doğal gazın payı hızla artmıştır. Önümüzdeki dönemlerde de yenilenebilir enerji kaynakları ile birlikte daha da artması beklenmektedir. Kömür ise daha çok elektrik üretiminde kullanılmıştır. Bu nedenle birincil enerji tüketimi içindeki payı \%34'tür. Ancak tüketilen kömürün yarısı ithal kaynaklardan karşılanmaktadır (Deloitte and Investment Promotion Agency, 2010:3).

Türkiye ekonomisi, enerji konusunda yurt içi üretimin yetersizliği nedeniyle diş enerji kaynaklarına her geçen y1l daha çok bağlanmaktadır. 2010 verilerine göre tüketilen ham petrolün ancak \%10,5'i ve doğal gazın da \%2,2'si yerli kaynaklardan karş1lanmakta, kalanı ise ithal edilmektedir. Zaman içinde yurt içi tüketimin yerli üretimi geçmesiyle Türkiye ekonomisinin enerjiaçısından dışa bağımlılığı artmıştır. 
A.YILMAZ - S. Ü. KELLECİ - A. BOSTAN

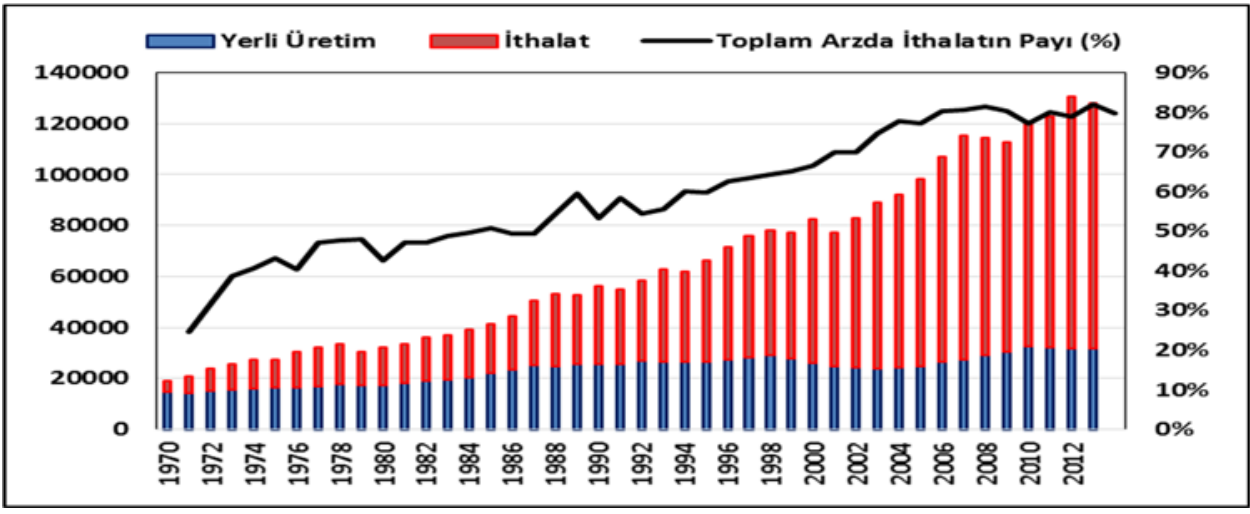

Şekil 2. Türkiye Ekonomisinin Enerjide Dışa Bağımlılı̆̆ (Btep) (ETKB, Enerji Dengesi Tabloları, 1970-2013)

Şekil 2'den de görüldüğü gibi, Türkiye ekonomisinde birincil enerji tüketimi 1970 y1lında 18.872 Btep'den 2013 yılında 120.291 Btep'e çıkmıştır. Buna karşın yerli üretim 1970 yllında 14.516 Btep’ten 2013 yllında ancak 31.944 Btep'ye çıkartılabilmiştir. Tüm periyotta tüketim dört kat artarken üretim sadece 1,2 kat arttırılabilmiştir. Dolayısıyla toplam tüketim içinde ithal enerjinin payı 1970 yılında \%24,6'dan 2013 yılında da \%79,8'e çıkmıştır (Ediger vd, 2006: 383).

Enerjide dışa bağımlılı̆̆ın en önemli nedenleri yerli kaynakların yetersiz olması, yetersiz üretim ve fosil tabanlı yakıtların yoğun kullanımıdır. Dışa bağımlılık özellikle petrol ve doğal gaz kaynaklarında söz konusudur. 2009 itibariyle Türkiye'nin üretilebilir petrol rezervi 299 milyon varildir. Doğal gaz rezervi ise 6,2 milyar $\mathrm{m}^{3}$ tür. Diğer yandan günlük petrol tüketimi 0,6-0,7 milyar varil ve doğalgaz tüketimi 0,105 milyar $\mathrm{m}^{3}$ tür. 2010 yılında 2,5 milyon ton petrol ve 726 milyon $\mathrm{m}^{3}$ doğal gaz üretilmiştir. Bunun yanında tüketime bakıldığında aynı yıl doğal gaz tüketiminin rekor seviyeye ulaştığı görülmektedir. Petrol tüketiminde ise 2009 yılından beri düşüş eğilimi devam etmektedir. 2010 y1lında Türkiye'nin petrol tüketimi 29,2 Mtep ve doğal gaz tüketimi 38,2 milyar $\mathrm{m}^{3}$ olmuştur. Dolayısıyla bu üretim/tüketim oranları Türkiye ekonomisini söz konusu kaynaklarda dışa bağımlı kılmaktadır. Türkiye tükettiği petrolün \%91'ini, doğal gazın \%82'sini ve kullandığı taş kömürünün \%82'sini ithal etmektedir (TPAO, 
2010). Bu sonuçlardan hareketle, Türkiye ekonomisinin tüketimdeki dışa bağımlılığı arz güvenliğini kırılgan hale getirdiği söylenebilmektedir.

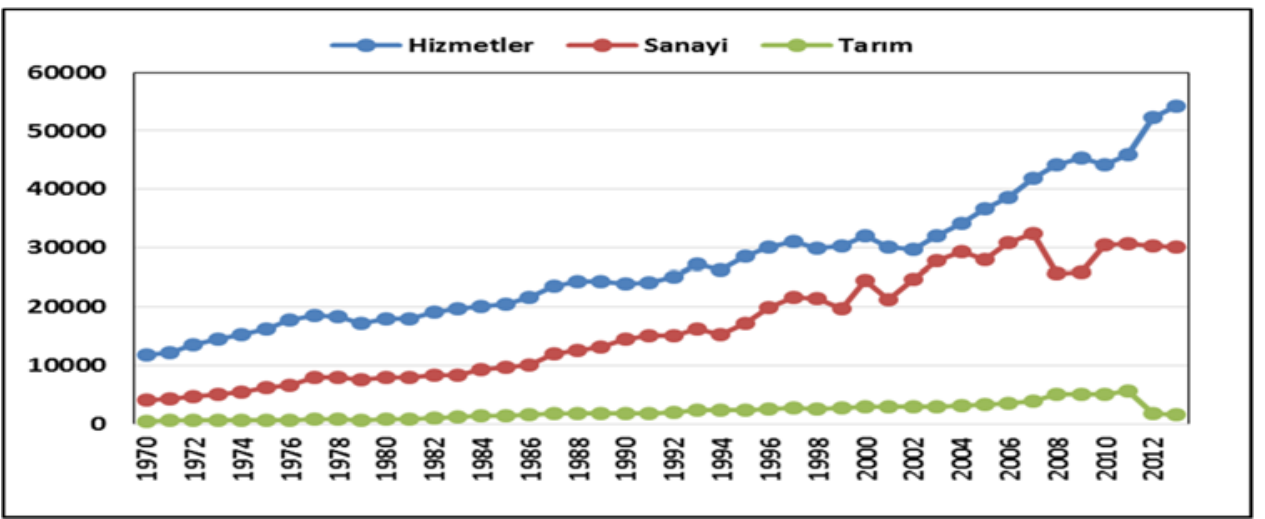

Şekil 3. Sektörel Enerji Tüketimi (Mtep) (ETKB Enerji Dengesi Tabloları 1970-2013)

Türkiye ekonomisindeki gelişimin her aşamasında sektörel enerji tüketiminin konjonktürel dalgalanmalardan, enerji politikalarından ve özelleştirme politikalarından etkilendiği görülmüştür. Sektörel enerji tüketiminde hizmetler sektörü en büyük paya sahiptir. Hizmetler sektörünü sanayi sekörü takip etmektedir. Ancak 1970’lerden günümüze gelirken hizmetler sektörünün sektörel enerji tüketimindeki payının azaldığı, sanayi sektörünün payının $\operatorname{arttığ}$ görülmektedir.1970 öncesinde enerji politikalarında öncelik, sanayi sektörünün ihtiyacını karşılamak ve elektrik tüketimini tüm yurda yaymak şeklinde belirlenmiştir. Enerji daha çok ısıtmada kullanılmış dolayısıyla hizmetler sektörü enerji tüketiminde ilk sırayı almıştır. Çünkü bu dönemlerde sanayi sektörü zayıf, şehirleşme oranı ise düşüktür. Fakat sanayi sektörünün milli gelir içindeki payının artmasına paralel olarak enerji tüketimi içindeki payı da artmış hizmetler sektörünün payı ise gerilemiştir (DTM, 2006:1-5)..

Şekil 3’ten de görüldüğü gibi, sektörel enerji tüketimi (çevrim ve enerji sektörü hariç) 1970 yllında 16.496 Btep'den 2013 yılında 85.911 Btep'ye çıkmıştır. Sektörel bazda incelendiğinde, 1970 yılında hizmetler sektöründe enerji tüketimi 11.684 Tep iken 2013 yılında 54.173 Btep olarak görülmektedir. Sanayi sektöründe enerji tüketimi 1970 yılında 4122 Btep iken 2013 yılında 30.138 Btep'ye olarak gerçekleşmiştir. Tarım sektöründe ise enerji tüketimi 1970’te 510 Btep iken 2013 


\section{A.YILMAZ - S. Ü. KELLECİ - A. BOSTAN}

y1lında ancak 1.633 Btep olmuştur. Özellikle hizmetler ve sanayi sektörlerinde enerji tüketiminin önemli ölçüde arttığı görülmektedir. Bununla birlikte, hizmetler sektörünün payı $\% 77$ 'den $\% 55$ 'e gerilerken sanayi sektörünün pay1 $\% 25$ 'ten $\% 38$ 'e ve tarım sektörünün payı \%3'ten \%6'ya çıkmıştır. 2013 yılında ise tarım sektörünün payında hızlı bir düşüş yaşanmıştır. Kriz yılları hariç sanayi sektörünün milli gelir içindeki payı sürekli artmıştır. Bu yüzden sanayi sektörü enerji tüketimi 2013 yılı itibariyle 30.138 Tep'ye ulaşmıştır. Tarım sektörü incelendiğinde, milli gelir içindeki payının görece küçük olması, yetersiz ölçek büyüklüğü ve modern tarım tekniklerinin yoksunluğu gibi nedenlerle tarım sektöründe enerji kullanımının sınırlı kaldığı görülmektedir.

Birincil enerji tüketimindeki hızlı artış, dış kaynaklara olan yüksek bağımlılık ve sanayi sektörünün payının hızla artması ile birlikte enerji alanında yapılan çalışmalar gittikçe artmaktadır. Bu çalışmaların, enerji politikalarının etkin bir şekilde belirlenmesinde yardımcı olabilmesi hedeflenmektedir. $\mathrm{Bu}$ noktada çalışmada da, Türkiye ekonomisi için ilk önce dönemler itibariyle genel ekonomideki enerji tüketimi daha sonra ise sektörel enerji tüketimi ayrıştırma yöntemiyle analiz edilecektir. Böylelikle enerji kullanımındaki etkiler ortaya konulmaya çalışılacaktır. $\mathrm{Bu}$ doğrultudada, enerji politikalarında öneriler geliştirilecektir.

\section{LITERATÜR TARAMASI}

Ayrıştırma analizi özellikle 1973 petrol krizinden sonra, batılı ülkelerde daha etkin, verimli, enerji krizi dönemlerinde krizi yönetebilecek enerji politikalarına ihtiyaç duyulmasından sonra geliştirilmiştir. Son yıllarda küresel 1sınmanın etkilerinin iyice hissedilmesiyle ayrıştırma analizi, sera gazı emisyonlarının analizinde ve küresel ısınmaya karşı daha etkin politikaların geliştirilmesinde kullanılmaya başlanmıştır. Günümüzde ise enerji fiyatlarındaki hızlı artış, fosil tabanlı yakıtların giderek azalan rezervleri, enerji tüketimi-ekonomik büyüme ilişkisinin etkileri gibi nedenlerle ayrıştırma analizi, enerji ile ilgili araştırmalarda kullanılmaya devam edilmektedir (Granel, 2003: 6-8). 
Greening ve diğerleri (1997), 1970-1992 döneminde 10 OECD ülkesi için enerji yoğunluğunu altı farklı ayrıştırma yöntemiyle incelemiştir. Sonuçlara göre, Average Weighting Divisia (AWD) ve Divisia (rolling year simple average) yöntemleri en iyi sonuçları verdiği tespit edilmiştir. Ampirik bulgulara göre, genel enerji yoğunluğu her bir alt sektörde enerji yoğunluklarında meydana gelen düşüşe bağlı olarak azalmıştır. Norveç gibi bazı ülkelerin daha enerji yoğun sektörlere yönelmeleri genel enerji yoğunluğundaki düşüş trendini olumsuz etkilemiştir. Halbuki Japonya, ABD, Almanya gibi ülkelerin daha az enerji yoğun endüstrilere yönelmeleri ise enerji yoğunluğundaki düşüşü desteklemiştir.

Cornillie ve Frankhauser (2004) çalışmasında,1992-1998 yılları için Orta ve Doğu Avrupa ile eski Sovyet bloku ülkelerinde enerji yoğunluklarını incelemiştir. Komünist blokun çözülmesinden sonra bu ülkelerde enerji yoğunluklarının azaldığ 1 gözlemlenmiştir. Ancak gelinen seviyenin halaOECD ülkeleri ortalamasından yüksek olduğu belirtilmiştir. Macaristan, Slovenya, Litvanya gibi ilk grup ülkelerde yapılan hızlı özelleştirme, fiyat liberalizasyonu ve kurumsal yeniden yapılandırma nedeniyle enerji yoğunluğu hızla düşmüştür. Polonya, Romanya ve Slovakya gibi ikinci grup ülkelerde, milli gelir içinde ağır sanayinin önemli bir yer tutması,teknolojik gerilik ve politik aktörlerin ekonominin yeniden yapılandırılması için zayıf irade göstermesi gibi nedenlerle enerji yoğunluğunun aynı kaldığı fakat ekonominin diğer sektörleri için gelişme sağlandığı belirlenmiştir. Üçüncü gruptaki ülkeler için ilk iki grubun tersine geçiş döneminde, özelleştirmelerin yapılamaması ve sanayi sektöründe yeniden yapılandırmanın gecikmesi gibi nedenlerleenerji yoğunluğunun daha da arttı̆g tespit edilmiştir.

Ediger ve Huvaz (2005), 1980-2010 dönemi için Türkiye ekonomisinde sektörel enerji tüketimini LDMI yöntemiyle incelemişlerdir. Sonuçlara göre enerji tüketimindeki artışın temel nedeni üretimdeki artıştır. Çıktı ve yapısal etkinin sektörel enerji tüketimini arttırdığı, yoğunluk etkisinin ise düşürdüğü görülmüştür. Çıktı etkisi sanayi ve hizmetler sektörlerinde daha baskın, tarım sektöründe ise zayıftır. Yine çıktı etkisi, 1989 öncesi dönemde hizmetler sektöründe, 1989 sonrasında ise sanayi sektöründe daha büyüktür. Yapısal etkiye bakıldığında en çok 


\section{A.YILMAZ - S. Ü. KELLECİ - A. BOSTAN}

hizmetler ve tarım sektöründe etkili olduğu görülmektedir. Yoğunluk etkisi ise yapısal etkinin tersine hizmetler sektöründe diğer iki sektörde olduğundan daha etkilidir. Ayrıştırma sonuçlarına göre Türkiye ekonomisi 1983-1987, 1990-1993 ve 1995-1997 olmak üzere üç istikrarlı döneme ayrılabilir. Tüm bu dönemlerde çıktı ve yapısal etki pozitifken yoğunluk etkisi negatiftir. İkinci olarak sektörel enerji tüketimindeki önemli değişiklikler 1982, 1988-1989 ve bu iki dönem arasında meydana geldiği tespit edilmiştir. 1994 ve 1998-2000 dönemlerindeki değişim ise daha çok ekonomik krizlerle ilgilidir. Enerjinin sektörel kullanımın zaman içinde yapısal değişikliğe uğramasında hızlı şehirleşmenin, hızlı ekonomik büyümenin, hızlı nüfus artışının ve milli gelir içinde tarım sektörünün payının azalıp, sanayi sektörünün payının artmasının etkili olduğu vurgulanmıştır.

Steenhof (2006), Çin sanayisi elektrik talebini 1998-2002 yılları arasında LasPeyers yöntemiyle incelemiştir. Sonuçlara göre elektrik tüketimi 1998-2002 yılları arasında çıktı etkisi nedeniyle artmıştır. Bunun yanında elektrik talebinde meydana gelen azalmanın enerji yoğunluklarındaki değişimden ve yapısal değişimden kaynaklanabileceği belirtilmiştir. Yani hızlı sanayileşmenin elektrik talebinde meydana getirdiği arttırıcı etki, verimlilik artışları ve yapısal etki tarafından dengelenmiştir. Üretimdeki artış beraberinde enerji talebinde artış meydana getirmiştir. Ancak ağır sanayi dallarında enerji verimliliğinde görülen iyileşmenin alt sektörel düzeyde enerji yoğunluğunu düşürdüğü görülmüştür.

Zamani (2006), İran ekonomisi için 1967-2003 dönemi endüstriyel ve tarımsal çıktı ile enerji tüketimleri arasındaki eş bütünleşme ve nedensellik ilişkisini incelemiştir. Sonuçlara göre uzun dönemde endüstriyel üretimden endüstride kullanılan doğal gaz tüketimi, petrol tüketimi ve elektrik tüketimine doğru granger nedensellik ilişkisi tespit edilmiştir. Aynı şekilde tarımsal çıktıdan, tarım sektöründeki doğal gaz tüketimine ve petrol tüketimine doğru nedensellik ilişkisi görülmüsstür. Kısa dönemde ise milli gelirden genel enerji tüketimine ve endüstriyel katma değerden endüstriyel enerji tüketimine doğru nedensellik tespit edilmiştir. 
Ma ve Stern (2007), 1980-2003 yılları arası Çin ekonomisinde enerji yoğunluğundaki değişimi Logaritmik Ortalama Divisia İndeksi (logaritmic mean divisia index-LMDI) yöntemiyle incelemiştir. Analiz sonucunda, teknolojik ilerlemenin enerji yoğunluğundaki düşüşün en önemli nedeni olduğu tespit edilmiştir. Çalışmada, endüstriyel ve alt endüstriyel düzeyde meydana gelen değişmelerin enerji yoğunluğunu arttırdığı görülmüsştür. Alt sektörler arasındaki üretim değişimine dayalı yapısal değişmenin ise genel enerji verimliliğini düşürdüğü sonucuna ulaşılmıştır. 2000 yılından beri gerçekte görülen enerji yoğunluğu artışı ise negatif teknolojik ilerlemeyle açıklanmaktadır. Son olarak sektörler arası yakıt karmasında meydana gelen değişimlerin enerji yoğunluğundaki değişime katkısının az olduğu belirlenmiştir.

Jobert ve Karanfil (2007), çalışmalarında Türkiye ekonomisi için 1960-2003 dönemi enerji tüketimi ve ekonomik büyüme arasındaki nedensellik ilişkisini iki farklı şekilde incelemişlerdir. Ilk olarak enerji tüketimi endüstriyel, evsel ve genel şeklinde ayrılarak incelenmiş, ikincisinde ise enerji tüketimindeki artışın farklı nedenleri dikkate alınarak enerji tüketimi ve ekonomik büyüme arasındaki uzun dönem ilişkiler incelenmiştir. Yapılan eş bütünleşme analizi ve granger nedensellik testi sonuçlarına göre enerji tüketimi ve ekonomik büyüme arasında eş bütünleşme ilişskisi tespit edilememiş ancak her iki değişken arasında granger nedensellik ilişkisi tespit edilmiştir. İkinci olarak endüstride yaratılan katma değer ve endüstriyel enerji tüketimi arasında aynı analizler yapılmış ve aynı şekilde eş bütünleşme ilişkisi tespit edilememiştir. Ancak enerji tüketiminden endüstriyel katma değere doğru nedensellik ilişkisi belirlenmiştir.

Lise ve Montfort (2007), Türkiye ekonomisi için enerji tüketimi ve ekonomik büyüme arasında uzun dönemli bir eş bütünleşme ilişkisi tespit edilmiştir. Ayrıca nedensellik ilişkisinin milli gelirden enerji tüketimine doğru olduğu belirtilmiştir.

Yılmaz ve Atak (2010), Türkiye ekonomisi için 1980-2005 dönemi enerji tüketimini ayrıştırma yöntemi ile incelemişlerdir. Çalışmada enerji tüketimi tarım, sanayi, ulaştırma ve hizmetler olmak üzere dört alt gruba ayrılmıştır. Sonuçlara 


\section{A.YILMAZ - S. Ü. KELLECİ - A. BOSTAN}

göre çıktı etkisi söz konusu sektörlerde enerji tüketimini arttırıcı etki yaparken, yoğunluk etkisinin tüketimi düşürücü etki yaptığı tespit edilmiştir.

Korkmaz ve Develi (2012), Türkiye ekonomisi için birincil enerji tüketimi ile GSYİH arasındaki nedensellik ilişkisi Türkiye'nin 1960-2009 dönemi yıllık verileri kullanılarak incelenmiştir. Çalışmada Johansen eşbütünleşme ve Granger nedensellik testleri kullanılmıştır. Johansen eşbütünleşme testi sonuçlarına göre ele alınandönem için değişkenler arasında uzun dönemli bir ilişkinin varlığ1 tespit edilmiştir. Ayrıca enerji tüketimi ile GSYİH arasında iki yönlü nedenselliğin varlığı gözlenmiştir.

Çınar ve Yılmazer (2015) enerji tüketimi ve ekonomik büyüme ilişkisini arz ve talep yönlü olmak üzere iki farklı yaklaşımla panel veri analizi yöntemini kullanarak ele almışlardır. 1990-2013 yıllarını kapsayan dönem için, Brezilya, Hindistan, Çin, Türkiye, Meksika, Güney Afrika, Şili ve Endonezya gibi yüksek büyüme performansı gösteren ülkeler baz alınmıştır. Arz yönlü yaklaşımda, yenilenebilirve yenilenemez enerji tüketiminin ekonomik büyümeye etkisi geleneksel üretim fonksiyonuile araştırılırken,talep yönlü yaklaşımda yenilenebilir enerji tüketimi, ekonomikbüyüme, karbondioksit emisyonu ve enerji fiyatları arasındaki ilişki incelenmiştir. Çalışmada, yenilenebilir enerji kaynaklarının ekonomik büyüme üzerindeki etkisi ve bukaynakların tüketimini belirleyen değişkenler incelenmeye çalışılmaktadır. Arz yönlü model yardımıyla, yenilenebilirkaynakların ekonomik büyüme üzerindeki etkisi; talep yönlü model yardımıyla yenilebilirenerji kaynaklarının belirleyicileri araştırılmıştır. Sonuçlara göre gelişmekte olan ülkelerde 1990-2013 dönemi için sürdürülebilir büyümeningerçekleşmesinde yenilenebilir enerji kaynaklarının belirleyici bir rol oynadığ 1 tespit edilmiştir.

\section{METOT ve VERI}

1970’li yıllarda yaşanan enerji şokları sonucunda, ayrıştırma analizi teknikleri, enerji verimliliği ile ilgili çalışmalarda kullanılmıştır. Bu tekniğin kullanıldığı çalışmalarda, sanayi değişimlerinin enerji kullanımı ve enerji verimliliği üzerindeki 
Dokuz Eylül Üniversitesi İktisadi ve İdari Bilimler Fakültesi Dergisi Cilt:31, Sayl:2, Yll:2016, ss. 1-27

değişikliklerin incelenmesi amaçlanmıştır. Bunun yanında, ayrıştırma analizi teknikleri özellikle ekonomik büyümenin, üretim faktörlerinin sektörler arası değişiminin ve teknolojik değişimin çevresel ve sosyo-ekonomik göstergeler üzerindeki etkisinin belirlenmesi amacıyla kullanılmıştır (Hoekstra, Berg, 2003: 40). Analize göre değişime uğrayan bir faktörün temel yıldaki (genellikle $\mathrm{T}_{0}$ olarak sembolize edilir) değeri ile daha sonraki yıl veya yıllardaki değeri (genellikle $\mathrm{T}_{1} \ldots . . \mathrm{n}$ olarak sembolize edilir)karşılaştırılır. Bu noktada araştırmacı isterse baz yı1 esaslı modeli (periodwise approach) isterse de zaman serisine dayalı modeli (time series) kullanabilir (Stenhof, 2006:377).

Ayrıştırma analizi iki temel kategoriye ayrılabilir; yapısal ayrıştırma analizi (SDA) ve endeks ayrıştırma analizi (IDA). SDA girdi çıktı katsayılarına ve girdi çıktı tablolarından üretilen nihai mal talebine bağlı iken, girdi çıktı modelinin aksine SDA yöntemi sabit katsayı varsayımı nedeniyle daha az kısıtlanmıştır. (Jungnitz, 2008:17). IDA yöntemi ise sektörel düzeydeki verilere dayanarak sadece dolaysız etkileri ölçmektedir. IDA tekniğinin asıl amacı sektörel düzeyde V değişkeninde meydana gelen değişikliği etkileyen temel sebep-sonuç ilişkilerini anlamaktır. Bunun da yolu V değişkeninde meydana gelen değişikliğin, değişikliğe neden olan parametreler cinsinden ifade edilmesindedir. IDA teknikleri enerji alanında ilk kez 1973 ve 1979 petrol krizlerinden sonra enerji tüketiminde meydana gelen değişiklikleri analiz edebilmek amacıyla kullanılmıştır. Basitliği ve esnekliği sayesinde uygulama alanları zamanla genişlemiştir (Granel, 2003: 7-9).

Literatürde çeşitli IDA yöntemleri vardır. Bu çalışmada toplamsal tipteki LMDI yöntemi seçilmiştir. Ang, Liu ve Chung (2004) ve Ang (2004-2005) yaptıkları çalışmalarda, daha küçük artık değer vermesi, içinde sıfır değerine sahip olan serileri de işleyebilmesi, toplamsal tutarlılık, kolay uygulanabilmesi ve yorumlanabilmesi nedeniyle LMDI yöntemini diğer yöntemlere tercih edilebileceğini belirtmişlerdir. Bu model Türkiye'de sektörel enerji tüketimini enerji yoğunluğu, yapısal değişim ve ekonomik çıktıdaki eğilimlere göre ayrıştırmaktadır. Model şöyledir;

$$
\Delta \mathrm{E}_{\text {tot }}=\Delta \mathrm{E}_{\text {act }}+\Delta \mathrm{E}_{\text {str }}+\Delta \mathrm{E}_{\text {int }}+\Delta \mathrm{E}_{\text {rsd }}
$$




\section{A.YILMAZ - S. Ü. KELLECİ - A. BOSTAN}

$\mathrm{Bu}$ formülasyona göre 0 y1lından $\mathrm{t}\left(\mathrm{E}_{\mathrm{tot}}\right)$ y1lına toplam birincil enerji tüketimindeki değişim, talepteki değişimin nedenleri olarak çıktı etkisi ( $\left.E_{\text {act }}\right)$, yapısal etki $\left(E_{\text {str }}\right)$, yoğunluk etkisi $\left(E_{\text {int }}\right)$ ve artık değer $\left(E_{\text {rsd }}\right)$ şeklinde dört kısıma ayrılabilir. Böylelikle her bir sektör için bu etkiler hesaplanabilir. Çıktı, yapısal ve yoğunluk etkileri için kullanılan modeller aşağıdaki gibidir;

$$
\begin{aligned}
& \Delta E_{a c t}=\sum_{i} \frac{E_{i}^{t}-E_{i}^{0}}{\ln E_{i}^{t}-\ln E_{i}^{0}} \ln \left(\frac{Q^{t}}{Q^{0}}\right) \\
& \Delta E_{\text {str }}=\sum_{i} \frac{E_{i}^{t}-E_{i}^{0}}{\ln E_{i}^{t}-\ln E_{i}^{0}} \ln \left(\frac{S_{i}^{t}}{S_{i}^{0}}\right) \\
& \Delta E_{\mathrm{int}}=\sum_{i} \frac{E_{i}^{t}-E_{i}^{0}}{\ln E_{i}^{t}-\ln E_{i}^{0}} \ln \left(\frac{I_{i}^{t}}{I_{i}^{0}}\right)
\end{aligned}
$$

Burada $E_{i}$ tep cinsinden i sektörü için toplam birincil enerji tüketimini, $Q^{0}$ ve $Q^{t}$ i sektöründeki 0 ve t yıllarındaki milyon TL cinsinden toplam üretimini, $S_{i}$ and $S_{i}^{0}$, i sektörünün 0 ve t yıllarında toplam üretim içindeki paylarını, $I_{i}^{t}$ and $I_{i}^{0}, \mathrm{i}$ sektörünün 0 ve t yıllarındaki enerji yoğunluklarını Tep/Milyon TL cinsinden verir.

Çalışmada kullanılan veriler Türkiye İstatistik Kurumu ile Enerji ve Tabii Kaynaklar bakanlığının internet sitesinden temin edilmiştir.Enerji tüketimi milyon ton eşdeğer petrol cinsinden gösterilirken, sektörlerin payları yüzde cinsinden, enerji yoğunlukları tep/TL cinsinden yani çıktı başı tüketilen enerji miktarı cinsinden verilmiştir.

Ekonomi hizmetler, sanayi ve tarım olmak üzereüç temel sektöre ayrılmıştır. Hizmetler sektörü ulaştırma, konut ve hizmetler ile diğer enerji tüketimlerini kapsamaktadır. Sanayi sektörü kimya-petrokimya, petrokimyasal hammadde, çimento, gübre, demir-çelik, şeker, demir dışı metaller ve diğer sanayi şeklinde yedi alt kısma ayrılmıştır. Tarım sektöründe ise alt ayrım yoktur. Son olarak enerji tüketimi içinde çevrim sektörü ve enerji dışı alanlar için kullanılan tüketim hariç tutulmuştur. 


\section{AMPİRIK SONUÇLAR}

Bu bölümde, daha önce belirtilen eşitlik 2, 3, ve 4 veri setine uygulanmış ve her bir etkinin enerji tüketimini nasıl etkilediği incelenmiştir. Analiz iki başlıkta yapılmıştır. İlk önce Türkiye ekonomisinin enerji tüketimindeki artış dönemlere ayrılarak incelenmiştir. İkinci olarak sektörel analiz yapılarak her bir etki tespit edilmeye çalışılmıştır.

\subsection{Genel Ekonomideki Enerji Tüketiminin Dönemlere Göre Analizi}

İlk olarak 1970-2013 dönemi için her bir etki hesaplanmış ve sonuçlar Tablo 1 'de verilmiştir.

Tablo 1. Genel Ekonomideki Enerji Tüketiminin Dönemlere Göre Ayrıştırması (19702013, Btep)

\begin{tabular}{|l|l|l|l|l|}
\hline \multirow{2}{*}{ Dönem } & Çıktı & Yapısal & Yoğunluk & \multirow{2}{*}{ Toplam } \\
\cline { 2 - 4 } & Etkisi & Etki & Etkisi & \\
\hline $1970-1979$ & 9.761 & 3.054 & -3.584 & 9.231 \\
\hline $1980-1989$ & 12.642 & 3.482 & -2.324 & 13.800 \\
\hline $1990-1999$ & 17.700 & 466 & -4.599 & 13.567 \\
\hline $2000-2013$ & 42.515 & 2.307 & -12.002 & 32.820 \\
\hline Toplam & 82.618 & 9.309 & -22.509 & 69.418 \\
\hline
\end{tabular}

Analiz sonuçlarına göre Türkiye'nin toplam enerji tüketimi tüm dönem itibariyle 69.418 Btep artmıştır. Bu artışa en önemli katkının çıktı etkisinden geldiği görülmektedir. Yapmış olduğu 82.618 Btep’lik katk1 ile toplam artışın \%118'ine kaynaklık etmiştir.Yapısal etkinin enerji tüketimini 9.309 Btep arttırdığ 1 ve \%13,4'lük bir katk1 yaptığı,buna karş1lık yoğunluk etkisinin ise azaltıcı rol oynadığ1 ve sektörel enerji tüketimine 22.509 Btep'lik düşürücü etki yaptığı tespit edilmiştir.

Dönemsel olarak enerji tüketimi değerlendirildiğinde tüketimin artan eğilim içinde olduğu görülmektedir. İthal ikameci dönemde (1970-1979) toplam tüketim, ekonominin ölçek olarak sınırlı büyümesi, 1973 ve 1979 krizlerinde enerji 


\section{A.YILMAZ - S. Ü. KELLECİ - A. BOSTAN}

fiyatlarında yaşanan dalgalanmalar, makroekonomik dengesizlikler ve politik istikrarsızlıklar gibi nedenlerle 9.231 Btep artmıştır. 1980 yılından itibaren ihracata dayalı kalkınma politikalarının başlamasıyla Türkiye ekonomisinin dışa açılması, ihracatın artması, kapasite kullanımının artması, hızlı kentleşme ve nüfus artışı ekonomik büyümeyi hızlandırmıştır. Dolayısıyla 1980 sonrasında enerji tüketimi artışı daha fazla olmuştur. Toplam nihai enerji tüketimi 1980-1989 döneminde 13.800 Tep, 1990-1999 döneminde 13.567 Btep ve 2000-2013 döneminde 32.820 Btep artmıştır.

Tablo 1 incelendiğinde, toplam tüketimdeki değişime en büyük katkının çıktı etkisinden geldiği görülmektedir. Diğer iki etkinin katkısı ise sınırlı olmuştur. Çünkü Türkiye Cumhuriyeti kuruluşundan itibaren tarım toplumundan sanayi toplumuna geçiş için çabalamaktadır. Kalkınma yolunda gelmiş olduğu nokta itibariyle de hizmetler sektörünün milli gelir içindeki payı gelişmiş ülkelerdeki kadar yüksek değildir. Ayrıca Türkiye ekonomisinde enerji verimliliği ve etkin enerji kullanımı yeterli seviyede değildir. Dolayısıyla enerji tüketimindeki artışın asıl kaynağı çıktı etkisidir.

Genel ekonomideki enerji tüketiminin ayrıştııılmasının 1970 yılından 2013 yılına kadarki dönemde yıllar itibariyle incelemesi Ek-1'de tablo olarak verilmiştir. Ek-1 tablo incelendiğinde, çıktı etkisinin 1990 yılından önceki seyrinin daha dalgalı olduğu görülmektedir. Enerji tüketiminin dalgalı olmasında özellikle 1980 yılından sonra ihracata dayalı kalkınma politikalarının benimsenmesi, dış rekabet, ekonomik büyümenin dalgalı seyri, enerji tüketimindeki artış, enerji piyasalarının da liberalizasyondan etkilenmesi ve çeşitli yıllarda yaşanan (1993, 1999, 2001 ve 2009) ekonomik krizler etkili olmuştur. Ayrıca çıtı etkisinin göreli büyüklüğü 1980 öncesi döneme göre daha fazla gerçekleşmiştir. Çünkü yeni dönemde ekonomik büyümenin hızlanması enerji ihtiyacını arttırmıştır.

Yapısal etki, tıpkı çıktı etkisi gibi pozitiftir ancak büyüklük olarak çıktı etkisinden oldukça küçüktür. Bu etki, tüm dönem boyunca genellikle düşük değerler almış ve istikrarlı seyretmiştir. Çıktı etkisi ile birlikte enerji tüketimini 
artırıcı etkide bulunmuştur. Cumhuriyetin ilk yıllarında tarımın milli gelir içindeki payı oldukça fazladır. Kullanılan tarım teknikleri ise modern değildir. Bu dönemde sanayinin gelişimi sınırlı olmuş milli gelir içindeki payı düşük kalmıştır. Bu yüzden Türkiye sanayisini güçlendirecek politikalar izlenmiş, tarım toplumundan sanayi toplumuna geçiş hızlandırılmaya çalışılmıştır. $\mathrm{Bu}$ politikaların sonucunda da sanayinin milli gelir içindeki payı artmış, tarımın payı ise azalmıştır. Dolayısıyla bu yöndeki yapısal bir değişimin, yapısal etkinin enerji tüketimini arttırıcı yönde etki yaptığı tespit edilmiştir.

Ekonomik çıktıdaki artış, enerji girdisindeki artıştan büyükse yoğunluk etkisi azalmaktadır. Bu durum, daha az enerji ile daha çok çıktı üretiliyor anlamını taşımaktadır. Tablo 1 incelendiğinde, çıktı ve yapısal etkinin tersine yoğunluk etkisinin negatif bölgede seyrettiği ve enerji tüketimini düşürücü etkide bulunduğu görülmektedir. 1970-1979 döneminde yoğunluk etkisinin enerji tüketimini 3584 Btep azalttığı sonucuna ulaşılmıştır.Özellikle 1980 yılından sonra ihracata dayalı kalkınmapolitikaları sonucunda yoğunluk etkisi düşme eğilimi içine girmiştir. Tıpkı çıktı etkisi gibi yoğunluk etkisi de 1980 yılından önce daha az dalgalı bir seyir izlemiştir (Ek-Tablo 1).

Ekonomi büyüdükçe ve dışa açıldıkça, enerji tüketimi arttıkça yoğunluk etkisi de daha inişli çıkışı bir seyir izlemeye başlamıştır. 1970-1979 döneminde ithal ikameci politikalar, ekonomide korumacılık anlayışı, hükümet müdahaleleri ve ekonomik faaliyetlerin sübvansiyonlarla desteklenmesi neticesinde enerji verimliliği ikinci plana itilmiş, üretimi arttırmak önem kazanmıştır. Ancak 1973 ve 1979 petrol krizleriyle fiyatlarda büyük dalgalanmalar yaşanmıştır.

1980 dönüşümüyle serbest piyasa ekonomisine geçiş, ihracatın artması, ekonomik büyümenin hızlanması, ekonominin dış rekabete açılması, ar-ge harcamalarının artması ve 1979 petrol krizi ile ham petrol fiyatlarının artması Türkiye ekonomisinde enerji verimliliğine ve enerji koruma politikalarına daha çok önem verilmesine neden olmuştur. 1980-1989 döneminde yoğunluk etkisi nedeniyle enerji tüketimi 2.324 Btep azalmıştır. Bu yeni dönemde ekonomi daha rekabetçi ve daha piyasa odaklı olarak çalışmıştır. İşte bu yeni ekonomik yapıda 


\section{A.YILMAZ - S. Ü. KELLECİ - A. BOSTAN}

enerji yoğunluğu kademeli olarak düşmeye başlamıştır. Ayrıca rekabetçi piyasa yapısında firmaların daha kar odaklı davranması ve ekonomik büyümenin hızlanması da enerji yoğunluğunun azalmasında etkili olduğu söylenebilir. 1990'lı yıllarda özellikle bilişim teknolojilerinde yaşanan hızlı gelişmeler sayesinde hizmetler sektöründe enerji tüketimi pek değişmemiştir. Dolayısıyla toplamda çıtı artışına karşın enerji tüketiminin oransal olarak artmaması bu dönemde yoğunluk etkisinin negatif değerler almasını getirmiştir. 1990-1999 döneminde yoğunluk etkisiyle enerji tüketimi 4.599 Btep azalmıştır. 2000-2013 döneminde ise rakam12.002 Btep olarak gerçekleşmiştir. 2000'li yıllarda da bilişim sektöründe ortaya çıkan yenilikler, teknolojinin gelişmesi yoğunluk etkisi sonucu enerji tüketimini azaltıcı bir etki yaratmıştır.

\subsection{Türkiye Ekonomisinde Sektörel Enerji Tüketimine Her Bir Etkinin}

\section{Katkısı}

Analizin bu bölümünde, Türkiye ekonomisindeki enerji tüketiminde her bir etkinin katkısı sektörel bazda incelenecektir.Sektörel bazda çıktı, yapısal ve yoğunluk etkisinin katkısı Tablo 2'de verilmiştir.

Tablo 2. Türkiye Ekonomisinde Sektörel Enerji Tüketimine Her Bir Etkinin Katkıs1 (19702013, Tep)

\begin{tabular}{|l|l|l|l|l|}
\hline & Hizmetler & Sanayi & Tarım & Toplam \\
\hline Çıktı etkisi & 48.687 & 28.568 & 3.850 & 81.105 \\
\hline Yoğunluk Etkisi & -13.814 & -8.664 & -31 & -22.509 \\
\hline Yapısal Etki & 7.443 & 4.672 & -2.860 & 9.255 \\
\hline Toplam & 42.316 & 24.576 & 959 & 67.850 \\
\hline
\end{tabular}

Tablo 2'de,sektörel enerji tüketiminin her bir etki bazında analiz edilmesi sonucu ulaşılan değerler verilmiştir. Tablo 2 incelendiğinde, çıktı etkisinin her sektör için pozitif çıktığı görülmektedir. Yani tüm sektörlerde üretimin artması kullanılan enerji miktarını arttırmıştır. Tablo 2'den görüldüğü üzere, çıktı etkisi tüm dönemde enerji tüketimini hizmetler sektöründe 48.687 Btep, sanayi 
sektöründe 28.568 Btep ve tarım sektöründe 3.850 Btep arttırmıştır. Benzer sonuçlar yapısal etki içinde elde edilmiştir. Tarım sektörü hariç yapısal etki enerji tüketimini arttırıcı etki yapmıştır. Yapısal etki enerji tüketimini hizmetler sektöründe 7.443 Btep ve sanayi sektründe 4.672 Btep arttırırken, tarım sektöründe 2.860 Btep azalttığı tespit edilmiştir.

Daha önce de belirtildiği gibi hizmetler ve sanayi sektörünün milli gelir içindeki payının artması yapısal etkiyi pozitif hale getirmiştir. Ancak tarım sektörünün payının azalması yapısal etkinin tarım sektöründe enerji tüketimini 1970-2013 dönemi için 2.860 Btep düşürmesine neden olmuştur. Yapısal ve çıktı etkisinin aksine yoğunluk etkisi hizmetler ve sanayi sektöründe enerji tüketimini düşürürken tarım sektöründe arttırmıştır.

Tablo 2'de de görüldüğü gibi, yoğunluk etkisi enerji tüketimini hizmetler sektöründe 13.814 BTep, sanayi sektöründe 8664 Btep ve tarım sektöründe de 31 Btep düşürmüştür. Türkiye İstatistik Kurumuile Enerji ve Tabii Kaynaklar Bakanlığı'nın verilerine göre, hizmetler ve sanayi sektörlerinde milli gelir 1970 yılından 2013 yılına sirasıyla $\% 476$ ve $\% 706$ büyürken enerji tüketimleri $\% 272$ ve \%643 oranında artmıştır. Halbuki tarım sektöründe milli gelir aynı dönemde sadece \%69 artarken enerji tüketimi \%897 oranında artmıştır. Yoğunluk etkisinin hizmetler ve sanayi sektörlerinde enerji tüketimini azalttı̆̆ını, tarım sektöründe ise arttırdığını bu bulgular göstermektedir. Sonuçta yoğunluk etkisinin tüm sektörler itibariyle enerji tüketimini 9.683 Btep düşürdüğü söylenebilmektedir.

Tablo 2'de sektörel enerji tüketiminin her bir etki bazında analiz edilmesi sonucu ulaşılan değerlerin verildiği belirtilmişti. Analizin devamında ise bu her bir sektör için çıktı, yapısal ve yoğunluk etkisinin seyri yıllar itibariyle incelenecektir. Bu bağlamda Şekil 4'te, hizmetler sektörü için çıktı etkisi, yapısal etki ve yoğunluk etkisi yıllık bazda gösterilmiştir. 
A.YILMAZ - S. Ü. KELLECİ - A. BOSTAN

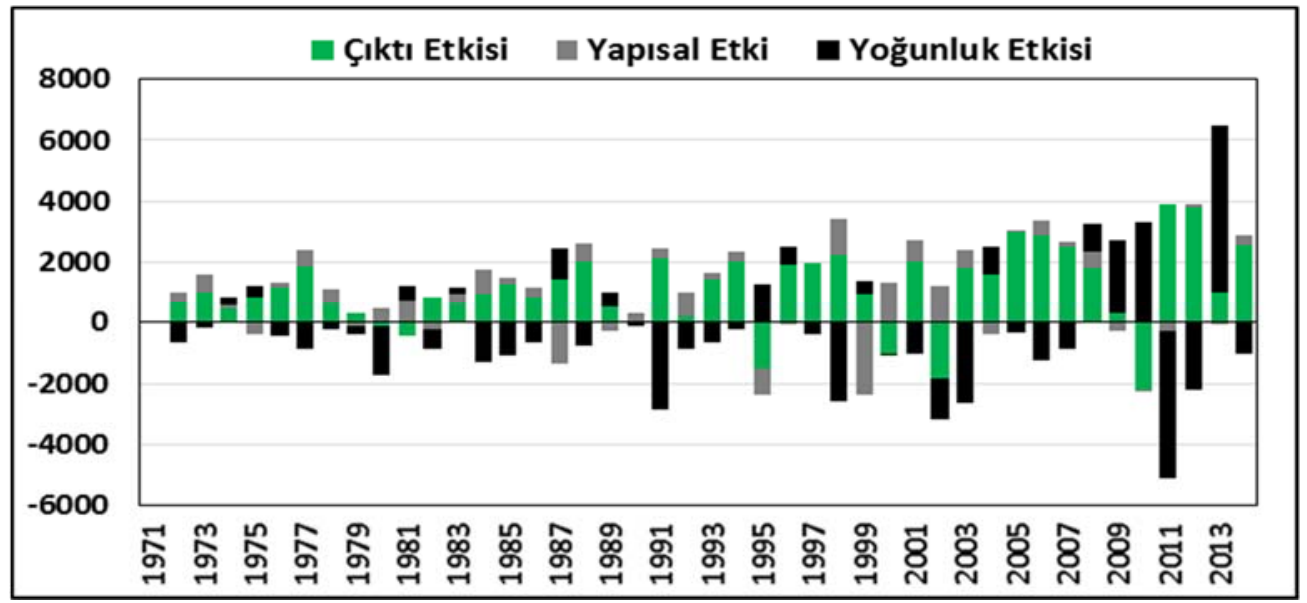

Şekil 4. Hizmetler Sektöründe Ayrıştırma Analizi (Btep)

Buna göre Türkiye ekonomisinin hizmetler sektöründe enerji tüketimindeki artışta en önemli faktörün çıktı etkisi olduğu söylenebilmektedir. Tüm periyod düşünüldüğünde, çıktı etkisi hizmetler sektörü için 1980, 1994, 1999, 2001 ve 2009 yılları hariç pozitiftir. Çıktı etkisi açısından değerlendirildiğinde, hizmetler sektöründeki enerji tüketimi artış1 48.687 Btep olmuştur. 1980 öncesinde hizmetler sektöründe tüketim seviyesinin daha düşük olduğu görülmektedir. Örneğin 19701979 arasında çıktı etkisi tüketimi 6901 Btep arttırırken, 1980-1989 arasında 8.221 Btep, 1990-1999 arasında 10.361 Btep ve 2000-2013 arasında 23.204 Btep arttırıc1 etki yapmıştır.

Benzer şekilde yapısal etki de hizmetler sektöründe birincil enerji tüketimini 7443 Btep artırmıştır. 1974, 1978, 1980, 1986, 1988, 1991, 1994, 1998, 1999, 2001, 2002, 2006 ve 2009 yılları hariç yapısal etki pozitiftir. Buna karşılık yoğunluk etkisinin önceki iki etkinin tersine tüm dönem itibariyle hizmetler sektöründe enerji tüketimini 10.367 Btep düşürdüğü görülmüştür. 1974, 1976, 1980, 1982, 1986, 1988, 1991, 1994, 1995, 1999, 2001, 2003, 2007, 2008 ve 2009 hariç hep negatiftir.

Türkiye ekonomisi için sanayi sektöründeki çıktı, yapısal ve yoğunluk etkisi de y1llar itibariyle Şekil 5’te gösterilmiştir. 


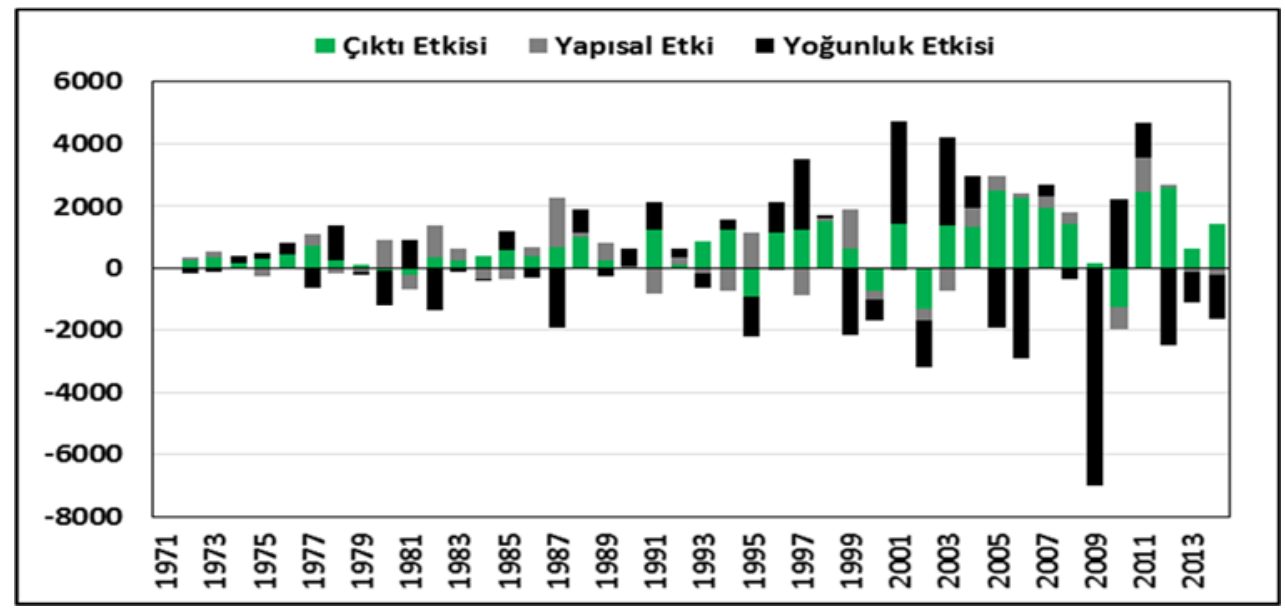

Şekil 5. Sanayi Sektörü Ayrıştırma Sonuçları (Tep)

Sanayi sektöründe de çıktı etkisi 1979, 1980, 1994, 1999, 2001 ve 2009 yılları hariç pozitiftir. Özellikle 1980 yılından sonra ekonomik büyüme hızlandıkça enerji tüketimi de artmıştır. Çıktı etkisi 1970-1979 dönemi için enerji tüketimini 2567 Btep; 1980-1989 dönemi için 3.838 Btep; 1990-1999 dönemi için 6.463 Btep ve 2000-2013 dönemi için 17.159 Btep arttırdığı görülmüştür. Toplamda ise çıktı etkisi sanayi sektöründe enerji tüketimini 28.568 Btep arttırmıştır. Benzer şekilde yapısal etki de sanayi sektöründe enerji tüketimini 4.672 Btep arttırıcı etki yapmıştır. Ancak bu etki çıktı etkisi kadar çok olmamıştır. 1974, 1977, 1978, 1980, 1983, 1984, 1990, 1992, 1995, 1996, 1998, 2000, 2001, 2002, 2010, 2012 ve 2013 yılları hariç pozitif olmuştur. Halbuki yoğunluk etkisinin tıpkı hizmetler sektöründe olduğu gibi sanayi sektöründe de 8.664 Btep'lik tasarrufa neden olduğu tespit edilmiştir. 1980 öncesinde sanayi sektörü enerji tüketimini 139 Btep ile düşük miktarda tasarruf etkisi yapmıştır. 24 Ocak kararlarıyla uygulamaya konulan programdan sonra yoğunluk etkisi, sanayi sektörü enerji tüketimini 1980-1989 dönemi için 1.127 Btep, 1990-1999 dönemi için 336 Btep'lik arttırmıştır. 20002013 dönemi için ise 7.733 Btep düşürmüştür.

Şekil 6'da ise tarım sektörü için çıktı, yapısal ve yoğunluk etkisinin 1971-2013 yılları arasındaki seyri görülmektedir. 
A.YILMAZ - S. Ü. KELLECİ - A. BOSTAN

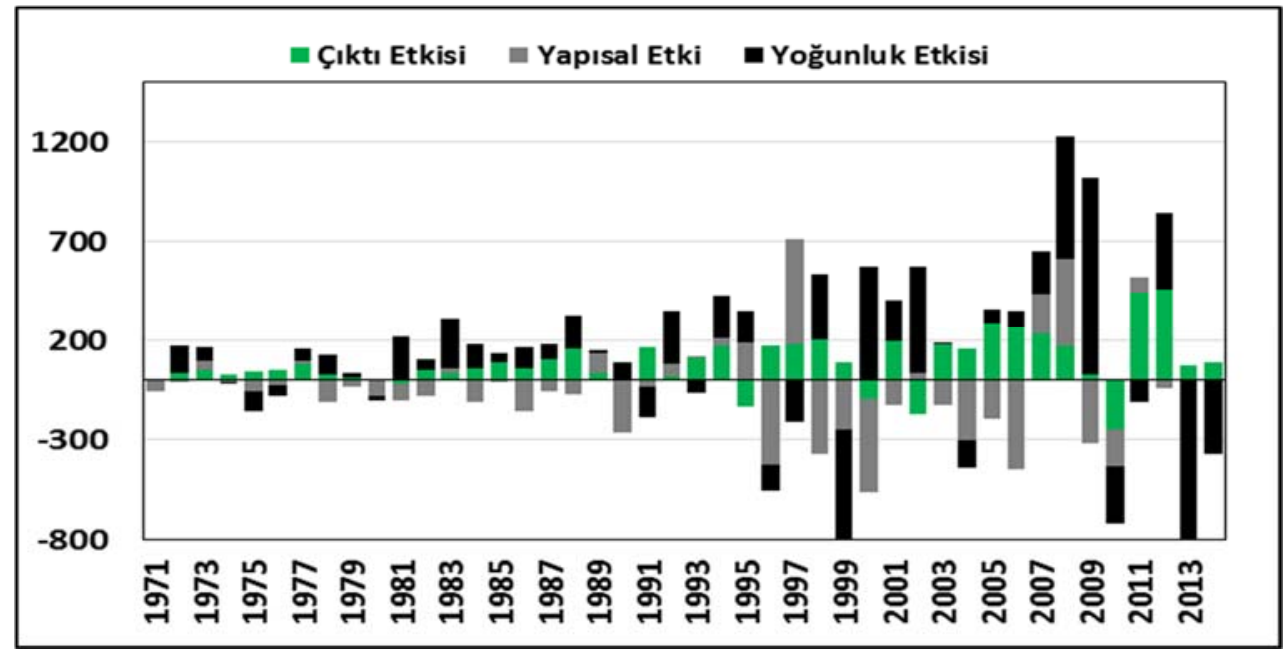

Şekil 6. Tarım Sektörü Ayrıştırma Analizi Sonuçları (Tep)

Şekil 6'dadagörüldüğü üzere,tarım sektörü, sanayi ve hizmetler sektöründen farklı bir yapı arz etmektedir. Milli gelir ve birincil enerji tüketimi içindeki sınırlı payı dolayısıyla her üç etkinin büyüklüğü diğer iki sektörde olduğundan daha azdır. Çıktı etkisi çoğunlukla pozitif değerler almıştır. Enerji tüketiminin 1970-1979 dönemi için 323 Btep, 1980-1989 dönemi için 584 Btep, 1990-1999 dönemi için 876 Btep ve 2000-2013 dönemi için 2.152 Btep arttırdı ğı tespit edilmiştir. Tüm dönem itibariyle neden olduğu artış ise 3.850 Btep'dir. Hizmetler ve sanayi sektörlerinin aksine tarım sektöründeki enerji tüketimi artışının asıl kaynağ 1 yoğunluk etkisidir. Yoğunluk etkisinin diğer sektörlerin aksine tarım sektöründe tüketimi arttırıcıbir rol üstlendiği söylenebilir. 1973, 1974, 1975, 1979, 1990, 1992, 1995, 1996, 1998, 2003, 2009, 2010, 2012 ve 2013 yılları hariç pozitiftir. Tüm dönem itibariyle sektörel enerji tüketimini 31 Btep düşürmüştür. Yapısal etkiye bakılırsa, hizmetler ve sanayi sektörünün aksine tarım sektöründe enerji tüketimini azaltıcı rol oynamıştır. Tüm dönem boyunca iseenerji tüketimini 2.806 Btep düşürdüğü belirlenmiştir.

\section{SONUÇ}

Endüstri devriminden beri enerji, ekonomik kalkınma ve büyümenin önemli kaynaklarından biri olmuştur. Dünya üzerinde insan yaşamı bir şekilde enerjiye 
bağımlıdır. Modern dünyada ulaştırmadan lojistiğe, iletişimden güvenliğe ve sağlığa kadar tüm alanlar da enerji en önemli girdilerden biri olmuştur. Türkiye gibi gelişmekte olan ülkeler söz konusu olunca enerjinin önemi daha da artmaktadır. Çünkü 2013 yılı itibariyle dünya birincil enerji tüketiminin \%56’sını gelişmekte olan ülkeler gerçekleştirmiştir ve bu oranın önümüzdeki dönemlerde de artması beklenmektedir. Enerji alanındaki pek çok çalışma göstermektedir ki yeterli miktar ve kalitede enerjiye hem düşük maliyetlerle ulaşılmalı hem de bunun çevreye verebileceği zarar minimize edilmelidir.

Ayrıştırma analizi sonuçları, sektörel enerji tüketimi ile üretim artışının yakından ilerlediğini göstermektedir. Ekonomik kriz yılları hariç üretim arttıkça kullanılan enerji miktarı artmaktadır. Çalışmada, çıktı etkisinin (tüketimdeki toplam büyümenin \%104'ü) Türkiye ekonomisindeki enerji tüketim artışının en önemli nedeni olduğu tespit edilmiştir. Ekonomideki enerji yoğun sektörlerin (çimento, kağıt, demir-çelik, rafineri) daha az enerji yoğun sektörlere göre (bilgi teknolojileri, yazılım sanayi gibi) önemli bir yer tutmasından dolayı toplam etkiye en büyük katkı çıktı etkisinden geldiği, diğer iki etkinin katkısının ise sınırlı kaldığ 1 görülmüştür. Ekonomik büyüme ile daha az enerji yoğun sektörlerin ve hizmetler sektörünün milli gelir içindeki payının ve buna bağlı olarak yoğunluk etkisi ile yapısal etkinin katkısının artması beklenmektedir. Diğer yandan çıktı etkisinin bu derece etkin olması enerji arz güvenliği açısından risk oluşturmaktadır. Çünkü Türkiye ekonomisinin dış enerji kaynaklarına bağımlılığı yüksektir. Enerji arzında bir kesinti olduğu takdirde toplam çıktıda aksaklık meydana gelmesi kaçınılmazdır. $\mathrm{Bu}$ bağlamda enerji politikalarında arz güvenliğine önem vermek, enerji kaynaklarını ülke ve kaynak çeşidi bakımından zenginleştirmek önemlidir.

Ayrıştırma analizi sonuçlarına göre yoğunluk etkisinin tüm dönem boyunca iki farklı eğilim izlediği tespit edilmiştir. 24 Ocak kararlarından önce artan eğilimdeyken, 1980 sonrasında uygulamaya konulan yeni ekonomik programla birlikte düşme eğilimine girmiştir. Tüm dönem sonunda ise enerji tüketimini 9683 Tep düşürmüştür. $\mathrm{Bu}$ eğilim Türkiye ekonomisinde sanayi ve hizmetler sektörlerinde etkin enerji yönetiminden ve enerji verimliliği tekniklerinden 


\section{A.YILMAZ - S. Ü. KELLECİ - A. BOSTAN}

yararlanıldığını göstermektedir. Türkiye buna rağmen enerji verimliliği ve enerji yoğunluğunda Avrupa ülkelerinin gerisindedir. Enerji yoğunluğundaki düşüş eğilimi de daha yavaştır. Bu yüzden Türkiye enerji koruma politikalarına ve enerji verimliliği tekniklerine daha çok önem vermelidir. Özellikle hizmetler sektöründeulaşım modlarının dağılımında denge sağlanmalı ve maliyetler düşürülmelidir. Halbuki karayolları, Türkiye'de ulaştırma sektöründe en büyük paya sahiptir. Demiryollarının, havayollarının ve denizyollarının uzun yıllar ihmal edilmesi neticesinde karayolları temel ulaşım tipi olmuştur. Karayollarının yolcu ve yük taşımacılığındaki payı \%90'ın üzerindedir.

Son olarak Türkiye ekonomisinde, bilgi teknolojileri gibi enerji yoğunluğu az olan sektörlere önem verilmelidir.Böylelikle hem enerji talebi üzerindeki bask1 azalacak hem de daha az enerji kullanarak daha çok katma değer yaratılabilecektir. Diğer yandan nihai kullanıcıların günlük hayatlarında enerji verimliliğine dikkat etmeleri konusundaki bilinç arttırılmalıdır. Ayrıca, doğal gaz, petrol ve elektrik dağıtım ve iletim sistemlerindeki kayıp ve kaçaklar mümkün olan en az orana indirilmelivegerekli rehabilitasyon yatırımları yapılmalıdır. Enerjinin korunması ve verimli kullanılmasında 1sı ve güç-kojenerasyon sistemleri, merkezi 1sınma, atık 1S1 ve gaz geri dönüşümü gibi enerji tasarruf tekniklerine gerekli yatırımlar yapılmalıdır.

Analiz sonuçları Türkiye ekonomisinde yapısal etkinin sanayi ve hizmetler sektöründe enerji tüketimini arttırdığını, tarım sektöründe ise düşürdüğünü göstermiştir. Nihai olarak toplamda enerji tüketimini 9.309 Btep arttırmıştır. Daha önce de değinildiği gibi sanayi ve hizmetler sektörünün milli gelir içindeki payının artması yapısal etkisini pozitife döndürmüş ve ilgili sektörlerde enerji tüketiminde artışa yol açmıştır. Tersine tarım sektörünün milli gelir içindeki payının azalması tarım sektöründe yapısal etkinin, enerji tüketiminde düşürücü etki göstermesine yol açmıştır. Halbuki daha az enerji yoğun sektörlerin milli gelir içindeki payının artarak yapısal etkinin enerji tüketiminde düşürücü etki göstermesi beklenir. Örneğin gelişmekte olan ülkelerde ileri malzemeler sektörü veya bilgi teknolojileri gibi enerji yoğunluğu az sektörlerin gelişimi gelişmiş ülkelerde olduğundan daha 
azdır. Böylelikle yapısal etki sadece enerji tüketimini düşürme eğilimi içine girmeyecek aynı zamanda enerji yoğunluğu daha hızlı düşecektir.

1980 dönüşümünden sonra dışa açılmanın hızlanması, hızlı nüfus artışı ve artan şehirleşme, ekonomik büyüme ve kalkınma gibi faktörlerin etkisiyle enerji tüketiminin önemli derecede değişim gösterdiği belirlenmiştir. Halbuki çıktı etkisi hala Türkiye ekonomisi enerji tüketim artışı üzerindeki en önemli faktördür ve enerji yoğunluğundaki düşüş eğilimi gelişmiş ülkelerdeki kadar hızlı değildir. Ayrıca Türkiye ekonomisinin dış enerji kaynaklarına bağımlılığı risk oluşturacak kadar yüksektir. $\mathrm{Bu}$ yüzden Türkiye ekonomisi kendi enerji kaynaklarını geliştirmeli, enerji arz güvenliğine daha çok önem vermeli, enerji yoğunluğu az olan sektörlerin milli gelir içindeki payını arttırmalıdır. Ayrıca yeni enerji santrallerine, dağıtım ve iletim şebekelerine, enerji üretimine daha çok yatırım yapmalı, sahip olduğu zengin yenilenebilir enerji potansiyelinden daha fazla yararlanmalıdır. Tüm bunların yanı sıra kullanıcılar enerji koruma politikaları ve enerji verimliliği konusunda daha çok bilinçlendirmelidir.

\section{KAYNAKÇA}

ANG B.W., LIU F. L., CHUNG H. S. (2004), "A Generalized Fischer Index Approach to Energy Decomposition Analysis", Energy Economics 26, 757-763.

ANG B. W. (2004), "Decomposition Analysis for Policy Making in Energy: Which Is Preferred Method?", Energy Policy, Volume 32.

ANG B. W. (2005), "The LMDI Approach to Decomposition Analysis; A Practical Guide?", Energy Policy, Volume 33.

CORNILLIE J., FRANKHAUSER S. (2004), "The Energy Intensity of Transition Countries", Energy Economics 26 (2004), 283-295.

ÇINAR, S., YILMAZER, M. (2015), "Yenilenebilir Enerji Kaynaklarının Belirleyicileri ve Ekonomik Büyüme İlişkisi: Gelişmekte Olan Ülkeler Örneği”, Dokuz Eylül Üniversitesi İktisadi ve İdari Bilimler Fakültesi Dergisi, Cilt:30, Say1:1, Y11:2015, ss. 55-78

DELLOITE (2010), Deloitte and Republic of Prime Ministry Investment Support and Promotion Agency (August 2010), Turkish Energy Industry Report, httpwww.invest.gov.tren-USinfocenterpublicationsDocuments

energy.industry.pdf. 


\section{A.YILMAZ - S. Ü. KELLECİ - A. BOSTAN}

DTM-Dış Ticaret Müsteşarlığı (2006), Türkiye'de Enerji Üretim ve Tüketimi http://www.dtm.gov.tr/dtmadmin/upload/EAD/KonjokturIzlemeDb/teut.doc (07.10.2014).

EDIGER, V., AKAR S., UĞURLU B. (2006), Forecasting Production of Fosil Fuel Sources, in Turkey Using a Comperative Regression and ARIMA Model, Energy Policy 34 (2006), 3836-3846.

EDIGER V. HUVAZ Ö. (2006), Examining the Sectoral Energy Use in Turkish Economy (1980-2000) With the Help of Decomposition Analysis, Energy Conversation and Management, Volume 47.

ETKB (Enerji ve Tabi Kaynaklar Bakanlığı) Enerji Dengesi Tabloları, 1970-2013.

GRANEL, F. (2003), A Comperative Analysis of Index Decomposition Methods, Master Thesis, National University of Singapore, Department of Industrial and Systems Engineering, Singapore.

GREENING L.A., WILLIAM B.D., Schipper L., Khrushch M. (1997), Comparison of Six Decomposition Methods: Application to Aggregate Energy Intensity for Manufacturing in 10 OECD Countries, Energy Economics 19 (1997) 375-390.

JOBERT T., and KARANFIL, F. (2007) Sectoral Energy Consumption by Source and Economic Growth: The case of Turkey, January 2007, Energy and Environmental Modeling 2007 24000019, EcoMod.

KORKMAZ, Ö. ve DEVELİ A. (2012), Türkiye'de Birincil Enerji Kullanımı, Üretimi ve Gayri Safi Yurt İçi Hasıla (GSYİH) Arasındaki İlişki, Dokuz Eylül Üniversitesi İktisadi ve İdari Bilimler Fakültesi Dergisi, Cilt:27, Sayı:2, Y11:2012, ss. $1-25$.

LISE W., and MONTFORT K., V. (2007) Energy Consumption and GDP in Turkey: Is There a Co-Integration Relationship?Energy Economics 29 (2007) 1166-1178.

MA C., STERN D. I. (2008), China's Changing Energy Intensity Trend; A Decomposition Analysis, Energy Economics 30 (2008) 1037-1053, Volume 30.

RME - Republic of Ministry of Economy, Turkey Economic Outlook, http://www.tcp.gov.tr/english/turkey/pdfView.cfm?subID=2 (12.09.2015). 
Dokuz Eylül Üniversitesi İktisadi ve İdari Bilimler Fakültesi Dergisi Cilt:31, Sayl:2, Yll:2016, ss. 1-27

STEENHOF, P. A. (2006), Decomposition of Electricity Demand in China's Industrial Sector, Science Direct Energy Economics, Energy Economics, Volume 28.

TPAO (2010), Oil and Natural Gas Sector Report 2010 http://www.tpao.gov.tr/tpfilesuserfilesfilesCrude_Oil_and_Natural_Gas_Sector_R eport-Updated.pdf, (22 Eylül 2014).

YILMAZ, M., and ATAK, M. (2010)Decomposition Analysis of Sectoral Energy Consumption in Turkey, Energy Sources, Part B: Economics, Planning, and Policy, 5:2, 224-231,DOI: 10.1080/15567240802533203.

ZAMANI, M. (2007) Energy Consumption and Economic Activities in Iran, Energy Economics 29 (2007) 1135-1140. 


\section{A.YILMAZ - S. Ü. KELLECİ - A. BOSTAN}

Ek-1. Yıllar İtibariyle Enerji Tüketiminin Her Bir Etki Bazında Ayrıştırılması

\begin{tabular}{|c|c|c|c|c|c|c|c|c|c|}
\hline Yillar & $\begin{array}{c}\text { Çıktı } \\
\text { Etkisi }\end{array}$ & $\begin{array}{c}\text { Yapısal } \\
\text { Etki }\end{array}$ & $\begin{array}{c}\text { Yoğunluk } \\
\text { Etkisi }\end{array}$ & Toplam Etki & Yillar & $\begin{array}{c}\text { Çıktı } \\
\text { Etkisi }\end{array}$ & $\begin{array}{c}\text { Yapısal } \\
\text { Etki }\end{array}$ & $\begin{array}{c}\text { Yoğunluk } \\
\text { Etkisi }\end{array}$ & Toplam Etki \\
\hline 1971 & 972.47 & 435.37 & -665.83 & 742 & 1993 & $3,434.05$ & -343.42 & 337.37 & 3,428 \\
\hline 1972 & $1,399.26$ & 737.42 & -187.67 & 1,949 & 1994 & $-2,527.63$ & 298.32 & 86.31 & $-2,143$ \\
\hline 1973 & 661.94 & 79.83 & 487.22 & 1,229 & 1995 & $3,211.86$ & -78.91 & $1,464.05$ & 4,597 \\
\hline 1974 & $1,209.56$ & -591.17 & 491.60 & 1,11 & 1996 & $3,436.78$ & -652.99 & $1,633.20$ & 4,417 \\
\hline 1975 & $1,671.94$ & 156.26 & -126.21 & 1,702 & 1997 & $3,942.78$ & 858.00 & $-2,152.78$ & 2,648 \\
\hline 1976 & $2,701.61$ & 846.29 & $-1,424.91$ & 2,123 & 1998 & $1,675.82$ & -583.16 & $-2,327.66$ & $-1,235$ \\
\hline 1977 & 914.88 & 307.68 & 996.43 & 2,219 & 1999 & $-1,840.36$ & 657.97 & -113.61 & $-1,296$ \\
\hline 1978 & 419.63 & -197.73 & -375.90 & -154 & 2000 & $3,689.87$ & 368.34 & $2,456.79$ & 6,515 \\
\hline 1979 & -159.94 & $1,280.01$ & $-2,779.08$ & $-1,659$ & 2001 & $-3,342.42$ & 417.95 & $-2,304.54$ & $-5,229$ \\
\hline 1980 & -640.13 & 235.43 & $1,628.71$ & 1,224 & 2002 & $3,349.63$ & -228.32 & 148.69 & 3,27 \\
\hline 1981 & $1,280.74$ & 725.64 & $-1,955.38$ & 51 & 2003 & $3,091.36$ & 293.39 & $1,827.24$ & 5,212 \\
\hline 1982 & 979.78 & 558.08 & 389.14 & 1,927 & 2004 & $5,803.08$ & 342.58 & $-2,207.67$ & 3,938 \\
\hline 1983 & $1,419.22$ & 386.64 & $-1,212.86$ & 593 & 2005 & $5,457.93$ & 305.58 & $-4,090.51$ & 1,673 \\
\hline 1984 & $1,965.24$ & -138.59 & -411.65 & 1,415 & 2006 & $4,723.69$ & 294.40 & -246.09 & 4,772 \\
\hline 1985 & $1,305.92$ & 479.86 & -834.78 & 951 & 2007 & $3,457.07$ & 404.64 & $1,178.28$ & 5,04 \\
\hline 1986 & $2,218.41$ & 244.74 & -816.14 & 1,647 & 2008 & 502.98 & -61.85 &,- 538.12 & $-3,097$ \\
\hline
\end{tabular}


Dokuz Eylül Üniversitesi İktisadi ve İdari Bilimler Fakültesi Dergisi

\begin{tabular}{|c|c|c|c|c|c|c|c|c|c|}
\hline $\mathbf{1 9 8 7}$ & $3,214.99$ & 538.24 & 150.77 & 3,904 & $\mathbf{2 0 0 9}$ & $-3,750.07$ & -317.06 & $5,270.13$ & 1,203 \\
\hline $\mathbf{1 9 8 8}$ & 799.47 & 226.68 & 249.85 & 1,276 & $\mathbf{2 0 1 0}$ & $6,842.83$ & 460.15 & $-3,811.98$ & 3,491 \\
\hline $\mathbf{1 9 8 9}$ & 98.39 & 225.47 & 488.14 & 812 & $\mathbf{2 0 1 1}$ & $6,828.03$ & 74.88 & $-4,304.91$ & 2,598 \\
\hline $\mathbf{1 9 9 0}$ & $3,545.72$ & -437.57 & $-2,085.15$ & 1,023 & $\mathbf{2 0 1 2}$ & $1,750.56$ & -111.47 & 468.92 & 2,108 \\
\hline $\mathbf{1 9 9 1}$ & 377.90 & 724.66 & -306.56 & 796 & $\mathbf{2 0 1 3}$ & $4,110.00$ & 63.89 & $-2,847.50$ & 1,326 \\
\hline $\mathbf{1 9 9 2}$ & $2,443.27$ & 23.31 & $-1,134.59$ & 1,332 & & & & & \\
\hline
\end{tabular}

